\title{
Sven Thatje \\ Campylonotus arntzianus, a new species of the Campylonotidae (Crustacea: Decapoda: Caridea) from the Scotia Sea (Antarctica)
}

Received: 7 August 2002/ Accepted: 24 November 2002/Published online: 7 February 2003

(C) Springer-Verlag 2003

\begin{abstract}
Two specimens of Campylonotus arntzianus sp. nov. were caught in the Antarctic Scotia Sea off Saunders Island $\left(57^{\circ} 40.31^{\prime} \mathrm{S}, 26^{\circ} 27.81^{\prime} \mathrm{W}\right)$ using an Agassiz trawl at one station (depth: $475-589 \mathrm{~m}$ ). The new species described here is the fifth representative of the monogeneric family Campylonotidae, and the first of the family south of the Antarctic Convergence. Campylonotus arntzianus sp. nov. is a shrimp of about $5 \mathrm{~cm}$ in total length. Due to similarities in adult morphology, C. arntzianus sp. nov. seems to be closely related to C. capensis, a deep-sea species from the Southern Atlantic Ocean. A simple key for the species identification of the Campylonotidae is provided.
\end{abstract}

\section{Introduction}

The family Campylonotidae Sollaud, 1913, was originally divided into the two genera Campylonotus Bate, 1888 and Bathypalaemonella Balss, 1914, the latter comprising a few members of deep-sea species (e.g. Bruce 1966; Pequegnat 1970; Wicksten and Méndez 1983). Due to an increasing number of new species with different morphological characters in the genus Bathypalaemonella, de Saint-Laurent (1985) transferred this genus from the Campylonotidae to the Bathypalaemonellidae. Recently, this family was divided into two genera (Cleva 2001).

Members of the genus Campylonotus are shallow sublittoral to deep-sea species, predominantly assigned to Subantarctic regions of the southern hemisphere (Thatje et al. 2001). Campylonotus vagans Bate, 1888, has been recorded from the southeastern Pacific on the Chilean coast (about $41-56^{\circ} \mathrm{S}$ ) by Retamal (1981), Gorny (1999), Thatje et al. (2001), and from the Argentine sector of the Southern Atlantic (Torti and Boschi 1973;

S. Thatje

Alfred Wegener Institute for Polar and Marine Research, P.O. Box 12016127515 , Bremerhaven, Germany

E-mail: sthatje@awi-bremerhaven.de
Boschi et al. 1992), extending north to the latitude of Buenos Aires (about $35^{\circ} \mathrm{S}$ ). That species was found from the shallow sublittoral down to about $300 \mathrm{~m}$ water depth. Campylonotus semistriatus Bate, 1888, seems to be exclusively restricted to the channel and fjord system of the Strait of Magellan and Tierra del Fuego at water depths of 150-500 m (Retamal 1981; Boschi et al. 1992; Thatje et al. 2001). The third species from the Atlantic sector, C. capensis Bate, 1888, is mainly known to occur as deep-sea shrimp along the continental platform of the Argentine Atlantic shelf north to the continental slope off Brazil, at depths ranging from 700 to $1,300 \mathrm{~m}$ (Boschi et al. 1992; Spivak 1997; Gorny 1999). However, this species was also found in shallower waters $(140 \mathrm{~m})$ at Marion Island (46 43 'S, 38 ${ }^{\circ} 4^{\prime} 30^{\prime \prime} \mathrm{E}$; Bate 1888; Yaldwyn 1960), which may indicate a more circumpolar distribution of the species. The only Indopacific representative of this genus is C. rathbunae Schmitt, 1926, which has been found in the Great Australian Bight and off the east coast of New Zealand at depths of 155-800 m (Yaldwyn 1960; Pike and Williamson 1966).

There is generally little knowledge of the life history of the Campylonotidae. Protandrous hermaphroditism is assumed for all four previously assigned campylonotid species (Yaldwyn 1960, 1966; Torti and Boschi 1973; Thatje and Lovrich 2003) and seems to be a pattern typical to the family (Yaldwyn 1960). These species seem to follow an abbreviated larval development, passing through a minimum of two zoeal stages and one decapodid stage (Pike and Williamson 1966; Thatje et al. 2001). This abbreviated development is already indicated by well-developed zoea I (for discussion, see Pike and Williamson 1966), but was only completely followed in laboratory cultures of larvae of $C$. vagans (Thatje and Lovrich 2003). Although, from an evolutionary point of view, first larvae are quite advanced in development, with respect to the complete palp divisions of the maxilla and the maxillule and the large pereiopodal exopods, it is among the most primitive caridean larvae (Pike and Williamson 1966; Thatje et al. 2001). Its systematic position on the basis of larval characteristics resulted in 
controversial discussion (see Borradaile 1907; Balss 1957; Pike and Williamson 1966; Thatje et al. 2001).

The present work gives a detailed description of a new representative of the Campylonotidae, C. arntzianus sp. nov. from waters off Saunders Island (South Sandwich Islands), and that is the first representative of the Campylonotidae for Antarctic waters.

\section{Materials and methods}

Two specimens of the new species were obtained from an Agassiz trawl (sampling depths: 475-589 m) at one station off Saunders

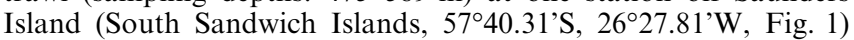
during the "Latinamerican Polarstern Study" (LAMPOS, ANT XIX/5, April 2002). Both specimens were photographed in order to record coloration previous to fixation. The specimens were fixed in $4 \%$ buffered formalin and later transferred into $70 \%$ ethanol. The paratype was dissected in the laboratory, and appendages and mouthparts drawn using a Zeiss stereomicroscope. The type material is deposited in the Crustacea collection of the Zoological Museum of the Humboldt University, Berlin, Germany.

\section{Results}

Systematics

Order Decapoda Latreille, 1803

Suborder Dendrobranchiata Bate, 1888

Superfamily Palaemonoidea Rafinesque, 1815

Family Campylonotidae Sollaud, 1913

\section{Diagnosis}

Genus Campylonotus Bate, 1888: first pair of pereiopods chelate, with only one movable finger; second pair of pereiopods equal; pereiopods without exopods; arthrobranchs and epipods at bases of first four pairs of pereiopods. Upper antennal flagellum simple. Basal part of rostrum with not more than five teeth, the first of which stands behind the middle of carapace (changed after Holthuis 1952, 1955; see also Yaldwyn 1960; Torti and Boschi 1973).

\section{Campylonotus arntzianus, new species}

Material examined Saunders Island (South Sandwich Islands, Scotia Sea, Antarctica). PFS Polarstern expedition "LAMPOS, ANT XIX/5"; sampling location, station no. PS61/207, 57 $40.31^{\prime} S, 6^{\circ} 27.81^{\prime} \mathrm{W}, 16$ April 2002 (Fig. 1). AGT sampling depth, 475-589 m. Two male specimens of Campylotonus arntzianus sp. nov., holotype, $\mathrm{CL}=11.1 \mathrm{~mm}, \mathrm{TL}=53.7 \mathrm{~mm}$; paratype, $\mathrm{CL}=10.3 \mathrm{~mm}, \mathrm{TL}=53.2 \mathrm{~mm}$. Zoological Museum of the Humboldt University, Berlin, Germany (reg. no. ZMB 27453) (Figs. 2, 3, 4).

Etymology The species is named after Prof. Dr. Wolf E. Arntz.

Diagnosis A robust prawn of medium size with prominent, blade-like rostrum slightly curved; rostral formula $6 / 4$ (rostral tip with 1 subapical tooth). Telson armed with one mesial tooth and three pairs of spines on posterior margin; six pairs of spines at distal third of surface near lateral margin.

Description Rostrum blade-like and slightly curved; rostral formula known is $6 / 4,3$ of upper teeth on rostrum proper and 2 posterior of orbit; rostral tip with 1 subapical tooth. Lower margin of rostrum with four pronounced teeth (Fig. 2).

Eyes black, round, corneas not reaching end of first segment of antennular peduncle (Fig. 2).

Carapace smooth, cylindrical, with anterolateral margin rounded. Carapace with branchiostegal and pterygostomian spines (Fig. 2B).
Fig. 1 Sampling location of Campylonotus arntzianus sp. nov. from the Scotia Sea, South Sandwich Islands, Antarctica (57 $\left.7^{\circ} 40.31^{\prime} \mathrm{S}, 2^{\circ} 27.81^{\prime} \mathrm{W}\right)$ Specimens were caught during the "Latinamerican Polarstern Study" (LAMPOS) in April 2002

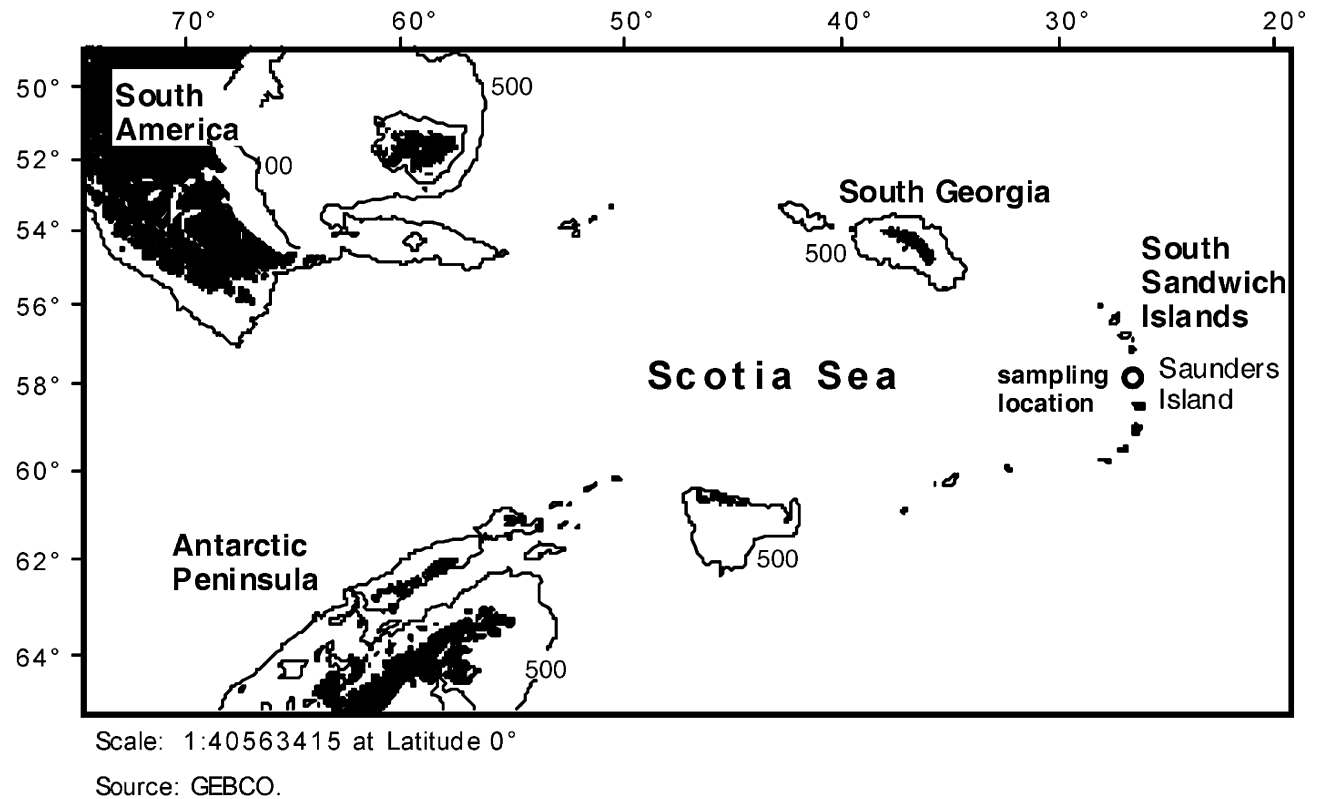


Fig. 2A, B Campylonotus arntzianus sp. nov. (ZMB 27453), holotype, male. A living holotype, lateral view; photograph by Martin Rauschert. B drawing. Scales $=1 \mathrm{~cm}$
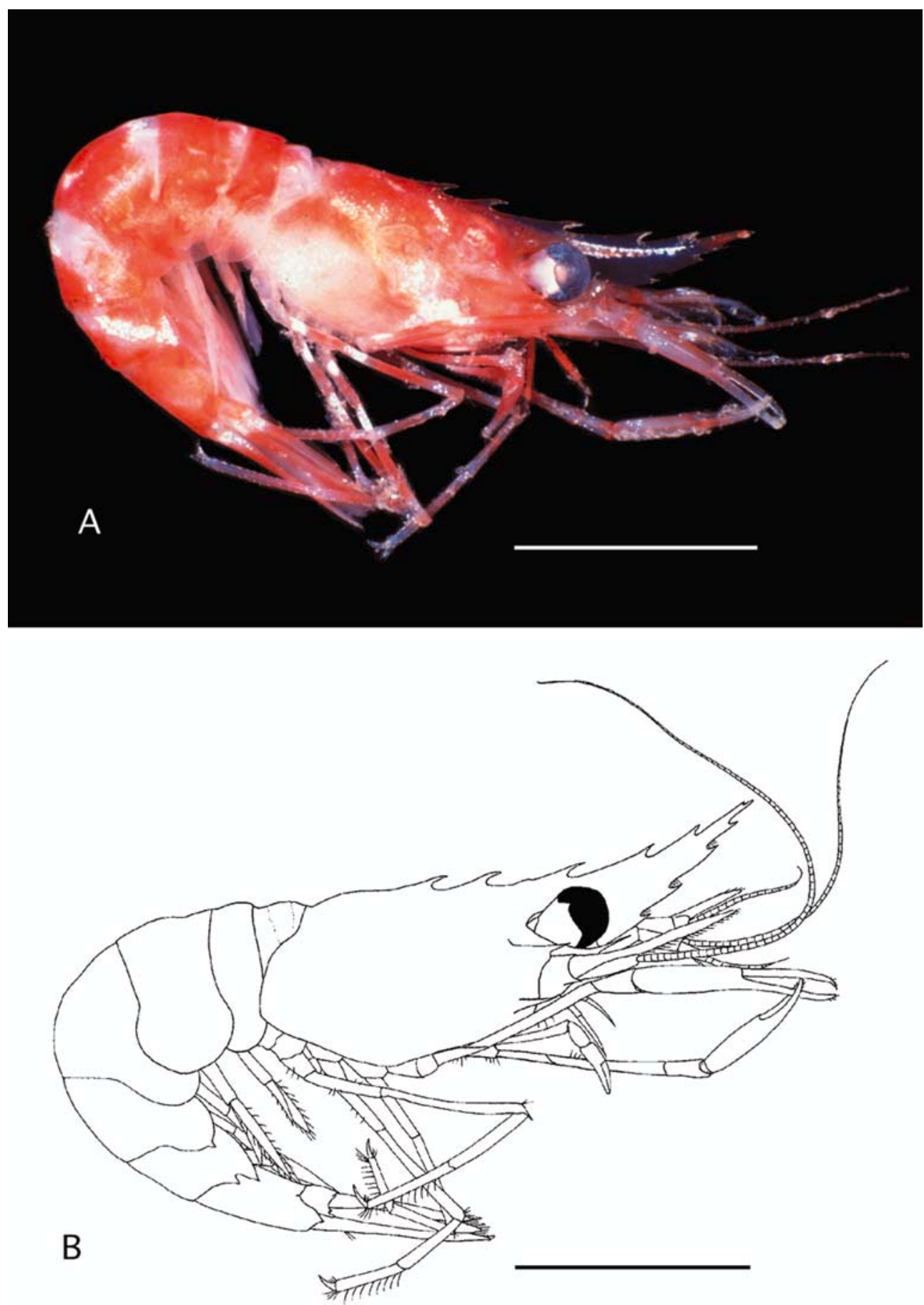

Antennular peduncle with slender first segment bearing long, tapering stylocerite, and widely expanded base. Stylocerite reaching about midway along second antennular peduncle, rather broad at base, narrowing gradually to sharp point. Third segment about two-thirds of second, both together about two-thirds of first (Fig. 3A). Outer flagellum of more than 20 segments; inner flagellum about half as long as outer. Inner margin of antennule with dense row of feathered setae, first antennular segment with row of 12 setae at outer margin (Fig. 3A).

Antennal scaphocerite about 3 times as long as broad (Fig. 3B), with straight lateral margin terminating in a strong tooth, which does not project beyond the rounded apex of the lamella. Inner margin with dense row of long feathered setae. Flagellum about twice as long as CL, first three segments broader. Inner margin of antennal basis terminating in a rounded hook.

Mandible with incisor and molar processes fused into one denticulate plate bearing strong cutting edge (Fig. 3C), palp absent.

Maxillule with proximal and distal endites armed with stout bristles (Fig. 3D). Endopod with long aesthetasc on inner apex; endopod bearing second apex at lateral third, with terminal feathered projecting setae; 

arntzianus sp. nov. (ZMB side. A antennule; B antenna; C mandible; D maxillule; E maxilla; $\mathbf{F}$ maxilliped 1; $\mathbf{G}$ maxilliped 2; $\mathbf{H}$ maxilliped 3. Scale bars $a=2 \mathrm{~mm}(\mathbf{A}, \mathbf{B})$; $b=2 \mathrm{~mm}(\mathbf{H}) ; c=1 \mathrm{~mm}(\mathbf{C})$; $d=2 \mathrm{~mm}(\mathbf{D}-\mathbf{G})$
Fig. 3A-H Campylonotus 27453), paratype, male, right
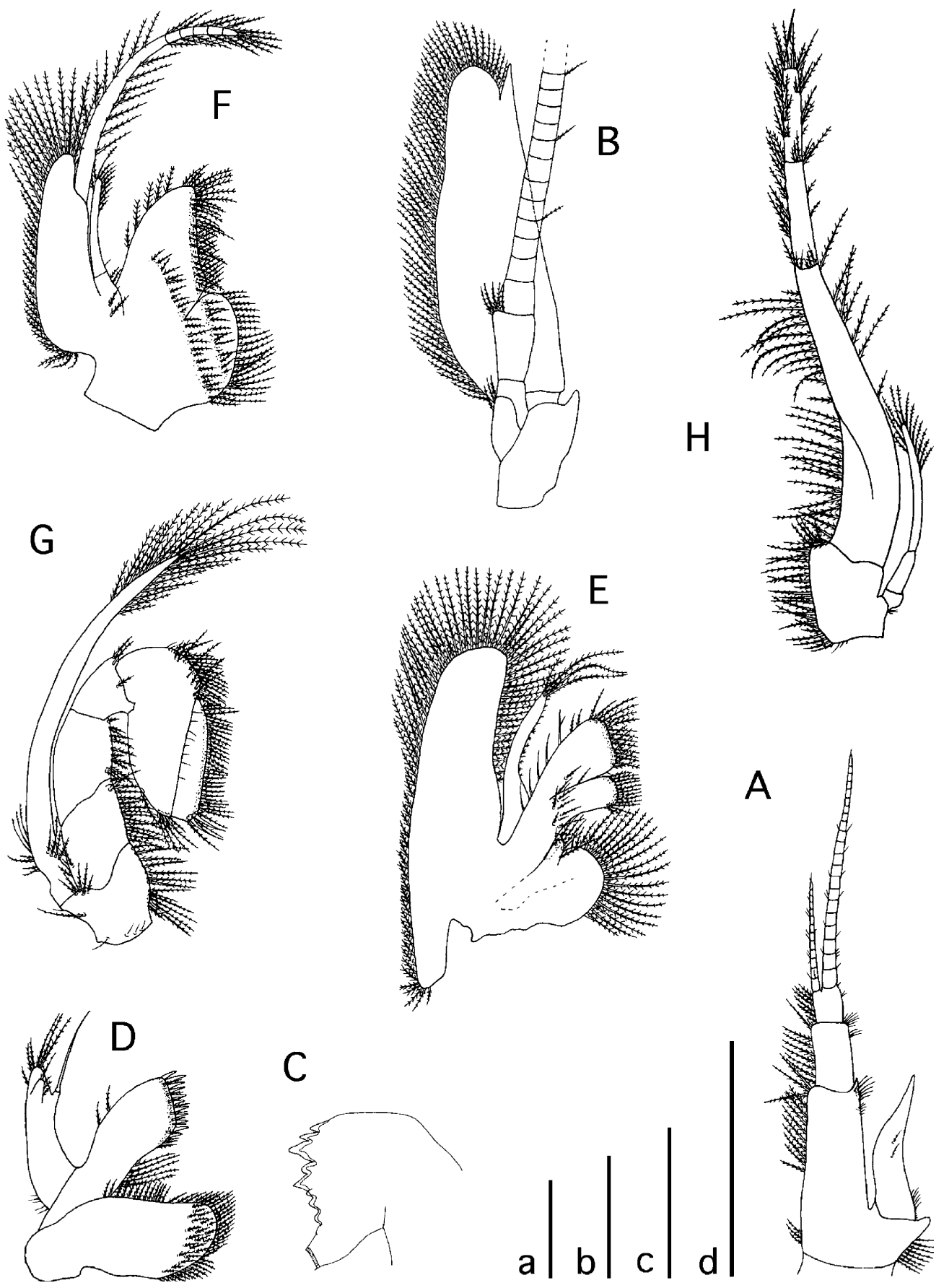

endopod ending in round apex with row of single feathered setae.

Maxilla with proximal endite unequally bilobed, armed with 65-70 and 7 feathered setae, respectively (Fig. 3E); distal endite well developed and strongly bilobed, together with more than 40 feathered setae. Endopod simple, with four long, slender, feathered apical setae. Scaphognathite large and fringed with feathered setae decreasing in length towards posterior lobe.

Maxilliped 1 with clearly separated proximal and distal endites (Fig. 3F); margins and surface of endites with dense cover of stout bristles; endopod bi-segmented, with apical tuft of setae; exopod with long palp (apical tip of five segments) and large caridean lobe fringed with long, feathered setae.

Maxilliped 2 with well-developed exopod separated from basis. Ischium, merus and carpus separated (Fig. 3G).

Maxilliped 3 with three-segmented exopod, of which first and second segments form a broad basis (Fig. 3H); exopod about half as long as ischium. Endopod of four segments ending in a short apical spine; internal margin with dense row of feathered setae.

Pereiopod 1 chelate (Fig. 4A). Dactylus slightly longer than half length of propodus; fingers of chela (especially tip) setose. Merus about twice as long as 
Fig. 4A-G Campylonotus arntzianus sp. nov. (ZMB 27453) paratype, male, right side. A pereiopod 1, lateral view; B pereiopod 2, lateral view; C pereiopod 3, lateral view; $\mathbf{D}$ pereiopod 4, lateral view; E pleopod 1, lateral view; $\mathbf{F}$ pleopod 2, lateral view; $\mathbf{G}$ telson and uropods, dorsal view. Scale bars: $a=1 \mathrm{~mm}(\mathbf{A}) ; b=2 \mathrm{~mm}(\mathbf{B}-\mathbf{D}$, $\mathbf{G}) ; c=2 \mathrm{~mm}(\mathbf{E}, \mathbf{F})$

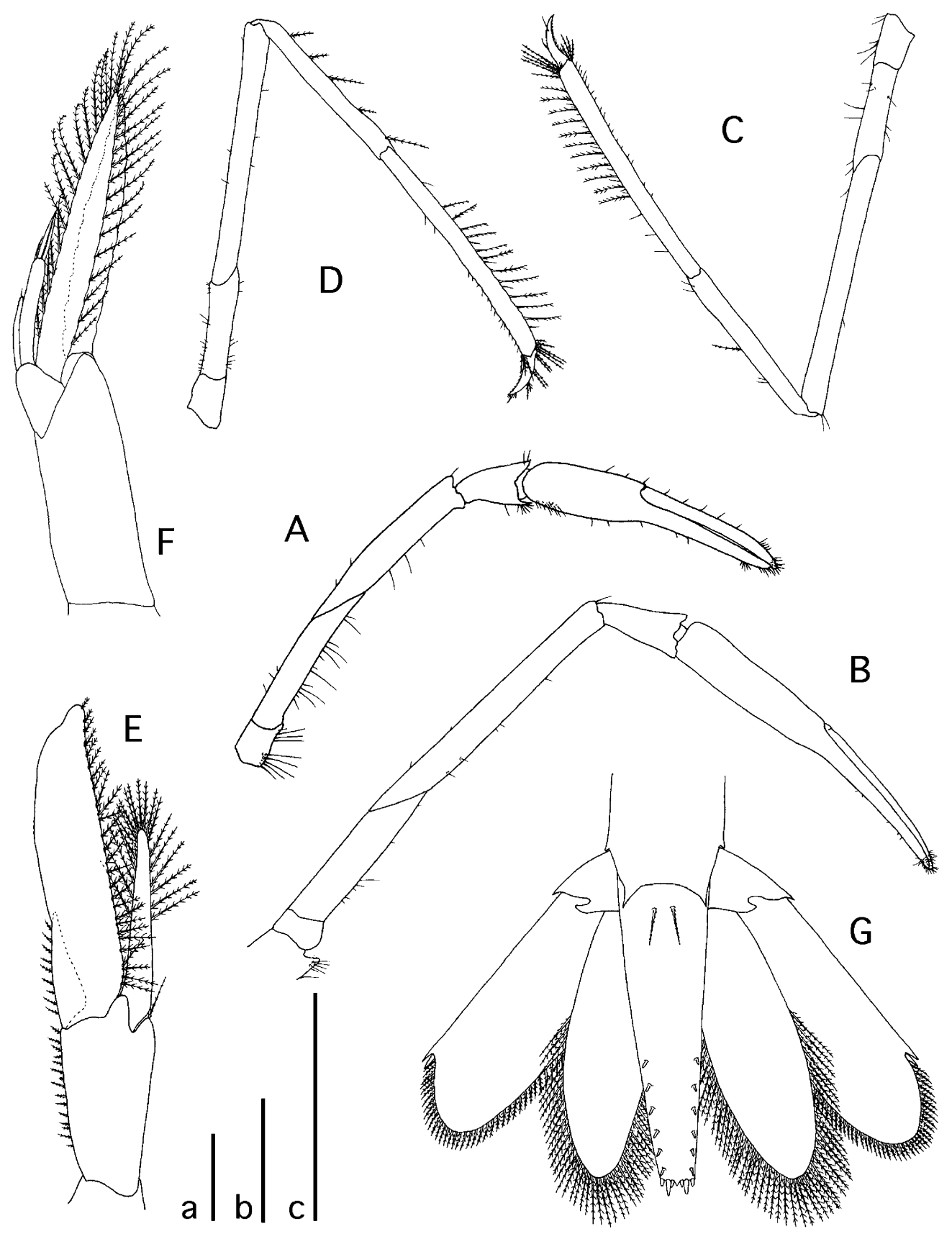

carpus, 1.2 times ischium; basis short, with two tufts of setae.

Pereiopod 2 chelate (Fig. 4B), almost twice as long as pereiopod 1. Dactylus slightly longer than half length of propodus; fingers of chela (especially tip) setose; propodus now with broader base. Merus about 3 times as long as carpus, twice as long as ischium; basis without setation.

Pereiopods 3-5 almost the same (Fig. 4C, D). Dactylus about one-quarter to one-fifth length of propodus and curves to terminate in a single, acute tip; the concave ventral surface bears several short acute bristles, brush-like; dorsal surface with several feathered setae in pereiopods 4 and 5 (Fig. 4D), pereiopod 3 with two to three spiny setae (Fig. 4C). Propodus and merus about 1.5 times as long as carpus; carpus about 1.5 times as long as ischium. All segments are scarcely covered with short, thin setae. Merus in pereiopod 5 with terminal spine (Fig. 2B).

First pleopod with broad endopod, 4 times as long as broad, 1.7 times as long as exopod, terminating in apical lobe (Fig. 4E); internal margin of basis and first third of endopod with row of short feathered setae; straightedged exopod tapering to acute tip; exopod fringed with about 20 long, feathered setae.

Second male pleopod with both endopod and exopod with weakly convex setose lateral and medial margins tapering to acute distal tips (Fig. 4F). Basis of endopod slightly expanded, bearing the appendix interna and masculina, 1.7 times as long the appendix interna; appendix masculina with three strong terminal aesthetascs. 
Pleurae of somites 1-5 rounded and expanded (Fig. 2B); pleura of somite 3 with small posteriorly directing tooth; posterior margin of the pleura of somite 5 with sharp tooth some distance above the sharply pointed apex. Somite 6 without expansion but pointed apex.

Uropods with endopod about as long as tail fan, exopod slightly longer (Fig. 4G). Exopod with straight lateral margin terminating in strong tooth. Both posterior margins of endopod end exopod with long, feathered setae; exopod with one additional lateral outer spine (Fig. 4G). Telson with straight lateral margins, narrowing posteriorly; posterior margin with mesial tooth and three pairs of apically rounded spines; lateral margins with six pairs of dorsal spines at distal third; telson dorsally with one pair of mesial, posteriorly projecting spines on first quarter; three to five mesial spines ventrally at distal third of telson (not indicated in drawing, Fig. 4G). Colour Living specimens were of bright, dark-orangered. Lateral sides of carapace changed to greyish-white; pereiopods irregularly striped white; somites with diffuse white stripes dispersing towards posterior margins. Both specimens obtained showed variable colouration, which I assume to be a general pattern in this species, as known from other Campylonotidae.

\section{Discussion}

Taxonomic remarks

Campylotonus arntzianus sp. nov. is closely related to C. capensis, but can undoubtedly be distinguished on the basis of morphological differences (compare with Bate 1888; Yaldwyn 1960; Torti and Boschi 1973). The main morphological characteristics separating both species are now listed (features of $C$. capensis in parentheses): rostrum slightly curved (strongly curved), with short bristles at basis of ventral teeth (without bristles); carapace without posterior tubercle (tubercle present); somite 4 with pleural tooth (absent); mandible without palp (with two-segmented palp); maxillipeds 1 and 2 without epipod (large epipod and podobranch present). The absence of the mandibular palp and the truncated scaphognathite in $C$. arntzianus sp. nov., which is tapering in all other campylonotid species, might be an indication of a different feeding mode.
General remarks

The benthic decapod fauna of the Antarctic is represented by only about ten natant species (Yaldwyn 1965; Kirkwood 1984; Tiefenbacher 1990), but these often occur in large concentrations and great biomass on the high-Antarctic shelf. Little is known of the decapod fauna south of the Antarctic Convergence or in the shallows along the Scotia Arc. The latter are assumed to serve as evolutionary footsteps between the Subantarctic Magellan Province of South America and the Antarctic Peninsula. Campylonotus was previously recorded as being exclusively Subantarctic, although Gorny (1999, Table 2) cited the occurrence of $C$. vagans on the Antarctic Shelf. I could not discover this Antarctic find during the re-examination of the literature cited in his work (Gorny 1999), and therefore assume it to be a mistake, or probably a confusion of the station data published by Holthuis (1952).

Decapod diversity in the Sandwich Islands area was low and completely different in species composition compared to stations obtained along the northern and southern branch of the Scotia Arc (Romero et al. 2003). In terms of community analyses, Ramos (1999) found a similar benthic faunal pattern as represented by poorly structured communities, including the absence of important suspension-feeder communities typical of the high Antarctic. Ramos (1999) assumed this indication to be due to active volcanism in this area (see also Acosta et al. 1989) serving as continuous disturbance. This find, however, can be confirmed by my own observations during the present scientific cruise to the area: sediments consist of lava and/or soft pumice stone, and no sponge or dense suspension-feeder communities were found at all. In addition to the present new species, two further caridean morphotypes were obtained from this area which have not yet been assigned to known taxa. This indicates that the natant decapod fauna is probably much higher in diversity in the Antarctic than previously assumed.

Campylonotus arntzianus sp. nov. is morphologically closely related to $C$. capensis, a deep-sea shrimp from the southern Atlantic. It is possible that colonisation of the Antarctic by decapod crustaceans is predominantly via the deep sea, where ecological conditions, such as low temperatures and food availability, are in some aspects

Key to species of Campylonotus Bate, 1888

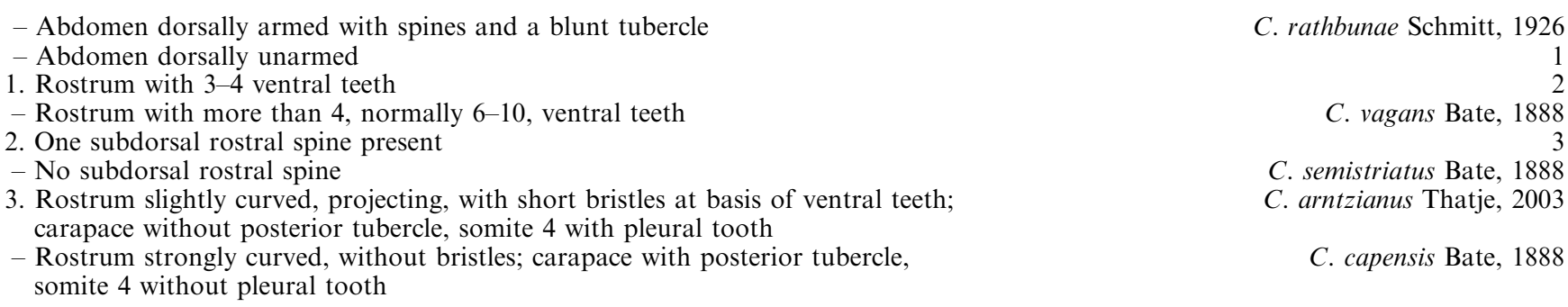


comparable to the Antarctic regime. Adaptation in the reproductive cycle, which I assume to be a clue for survival in polar areas, is often comparable, and might therefore be one key factor for successful colonisation of this area. The same evolutionary pathway has been already suggested for Chorismus tuberculatus (Thatje and Bacardit 2000), a deep-water caridean from the southern Atlantic Ocean.

Acknowledgements This paper is dedicated to Professor Dr. Wolf Arntz (Alfred Wegener Institute, Germany) on the occasion of his 60th birthday. In addition to his extensive research on Antarctic decapods and invertebrate communities in general, he encouraged my own interest in this subject and greatly supported my scientific work. I am indebted to Dr. Martin Boche and his crew of the German PFS Polarstern for help and assistance at sea, and to Dr. Gustavo Lovrich, M. Carolina Romero, Federico Tapella and Fabian Vanella for the excellent working atmosphere and fruitful research during this cruise. Dr. Martin Rauschert kindly provided the holotype photograph published in this work. I am grateful to Dr. Pablo J. López-Gonzalez and two anonymous reviewers for their helpful comments on the manuscript. I would like to thank Ruth Alheit for her revision of the English.

\section{References}

Acosta J, Canals M, Herranz P, Sanz JL (1989) Investigación geológica-geofísica y sedimentológica en el Arco de Escocia y península Antártida. In: Mapa (ed) Resultados de la campaña “ANTARTIDA 8611”. Publ Espec Inst Esp Oceanogr no 2, Madrid, pp 9-82

Balss H (1957) Bronn's Kleine Ordnung des Tierreichs. 1. Part 7. Buch Decapoda, VIII Systematik, pp 1505-1567

Bate CS (1888) Report of the Crustacea Macrura dredged by "H.M.S. Challenger" during the years 1873-1876. Rep Sci Res Voyage Challenger 1873-1876 Zool 24:768-778

Borradaile LA (1907) On the classification of the decapod crustaceans. Ann Mag Nat Hist 19:457-486

Boschi EE, Fischbach CE, Iorio MI (1992) Catálogo ilustrado de los crustáceos estamatópodos y decápodos marinos de Argentina. Frente Mar Montevideo 10:7-94

Bruce AJ (1966) Bathypalaemonella humilis sp. nov., a new species of shrimp from the South China Sea (Decapoda, Campylonotidae). Crustaceana 11:277-287

Cleva R (2001) Les Bathypalaemonellidae de Saint-Laurent, 1985 (Crustacea, Decapoda, Caridea) avec description d'une espèce nouvelle et défintion d'un genre nouveau. Zoosytema 23:757782

Gorny M (1999) On the biogeography and ecology of the Southern Ocean decapod fauna. Sci Mar 63 [Suppl 1]:367-382

Holthuis LB (1952) The Crustacea Decapoda Macrura of Chile. Reports of the Lund University Chile Expedition 1948-1949. Lunds Univ Arsskr Avd 2 47:1-110
Holthuis LB (1955) The recent genera of the caridean and stenopodidean shrimps (Class Crustacea, Order Decapoda, Supersection Natantia) with keys for their determination. Zoologische Verhandelingen. Brill, Leiden

Kirkwood JM (1984) A guide to the Decapoda of the Southern Ocean. ANARE Res Notes 11:47

Pequegnat LH (1970) Contribution on the biology of the Gulf of Mexico. 4. Deep-sea caridean shrimps with descriptions of six new species. Texas A\&M Univ Oceanogr Stud 1:59-123

Pike RB, Williamson DI (1966) The first zoeal stage of Campylonotus rathbunae Schmitt and its bearing on the systematical position of the Campylonotidae (Decapoda, Caridea). Trans $\mathrm{R}$ Soc N Z Zool 7:209-213

Ramos A (1999) The megazoobenthos of the Scotia Arc Islands. Sci Mar 63 [Suppl 1]:171-182

Retamal MA (1981) Catálogo ilustrado de los crustáceos decápodos de Chile. Gayana Zool 44:1-110

Romero MC, Tapella F, Lovrich GA, Thatje S (2003) Reproductive modes and distribution of benthic decapod crustaceans along the Scotia Arc. Rep Polar Mar Res (in press)

Saint-Laurent M de (1985) Remarques sur la distribution des Crustacés Décapodes. In: Laubier L, Monniot C (eds) Peuplements profonds du golfe de Gascogne, Campagnes Biogas. IFREMER, Brest, pp 469-478

Spivak ED (1997) Los crustáceos decápodos del Atlántico sudoccidental $\left(25^{\circ}-55^{\circ} \mathrm{S}\right)$ : distribución y ciclos de vida. Invest Mar Valparaíso 25:73-92

Thatje S, Bacardit R (2000) Larval stages of Chorismus tuberculatus (Decapoda: Caridea: Hippolytidae) from the south-western Atlantic Ocean. J Mar Biol Assoc UK 80:465-471

Thatje S, Lovrich GA (2003) Decapodid and early juvenile development in the protandrous shrimp Campylonotus vagans Bate, 1888 (Crustacea: Decapoda: Caridea), with notes on larval morphology. J Mar Biol Assoc UK 83:103-109

Thatje S, Bacardit R, Romero MC, Tapella F, Lovrich GA (2001) Description and key to the zoeal stages of the Campylonotidae (Decapoda, Caridea) from the Magellan Region. J Crust Biol $21: 492-505$

Tiefenbacher L (1990) Eualus kinzeri, a new hippolytid shrimp from the Weddell Sea (Antarctica) (Crustacea: Decapoda: Natantia). Spixiana 13:117-120

Torti MR, Boschi EE (1973) Nuevos aportes al conocimiento de los crustáceos decápodos Caridea del genero Campylonotus Bate, 1888. Physis Secc A Buenos Aires 32:65-84

Wicksten MK, Méndez GM (1983) Bathypalaemonella delsolari, a new species of shrimp from Peru (Decapoda, Caridea, Campylonotidae). Crustaceana 45:225-231

Yaldwyn JC (1960) Crustacea Decapoda Natantia from the Chatham Rise; a deep water bottom fauna from New Zealand. Biological Results of the Chatham Island 1954 Expedition. NZ Dep Sci Ind Res Bull 139:13-53

Yaldwyn JC (1965) Antarctic and subantarctic decapod Crustacea In: Mieghem J van, Oye P van (eds) Biogeography and ecology in the Antarctic. Junk, The Hague, pp 324-332

Yaldwyn JC (1966) Protandrous hermaphroditism in decapod prawns of the families Hippolytidae and Campylonotidae. Nature 209:1366 